\title{
Clinical Observations Elapsed Time
}

National Cancer Institute

\section{Source}

National Cancer Institute. Clinical Observations Elapsed Time. NCI Thesaurus. Code

C119800.

The interval between two clinical observation reference time points. 